\title{
A STUDY ON THE GEOLOGY OF THE ȚAGA REGION (CLUJ DISTRICT) ${ }^{1}$
}

\author{
IOAN MÂRZA ${ }^{2}$
}

\begin{abstract}
The geological formations from Taga area (Cluj District) are Sarmatian in age (in outcrops) and Badenian (under surface). Lithologically, they are represented mainly by sands and sometimes fine sediments (clays, marls), interbedded with volcanic tuffs a low fossil content. The Badenian is the host of gas accumulations, concentrated in dome structures.
\end{abstract}

Key words: stratigraphy, petrology, tectonics, Țaga

Localization: the rural community of Țaga is located East of Cluj District, at the border with Bistrița - Năsăud District.

Relief and hydrography: this region with large hilly areas belongs to the transition zone from the "Transylvania Plain" (S) towards the Someşan Plateau (N). The highest hills are between 400 to $500 \mathrm{~m}$ (the Bocor Hill is over $500 \mathrm{~m}$ high). The cuesta relief that corresponds to the unconformable valley slopes is well represented. The main hydrographic collector is the Fizes Valley (from SE to NW) together with its numerous tributaries; within the frame of this valley and its affluents there are extensive marsh lands and lakes formed from a mixed origin (due to natural - earth slipping- and anthropogenous factors). This natural phenomenon originates in tectonic consequences, the rise of the confluence zone of the Fizes Valley, due to diapirism. The most well known lakes are those from Țaga, Geaca, Cătina, and Sântejude. Maxim (1935) examined the evolution of this region's valleys, while Săndulache (1970) covered a study of the lakes.

\section{A review of geological research studies:}

- Koch (1900) - in the Taga area the "Plain Strata" (Stratele de Câmpie) are developed (Middle Miocene).

- Wein (1941 - 1942) - focus on the stratigraphy of the Buza-Năsal perimeter, as related to a nondenominated tuff level, and notes the lack of fossils (mentions a few Ervilia examples).

- Mârza $(1960,1962)$ - identifies the Ghiriş Tuff in the region and follows it through to Ocna Mureş (Uioara), proves its continuity, identifies the geological formations as belonging to the Sarmatian, and discovers more fossil occurrences (Ervilia and Abra), including the fossil level located under the Ghiriş Tuff.

- Sabău $(1984)^{3}$ - his thesis on the Țaga gas structure focus on the lithology of the formations and their paleonthologic content (micro and macro fauna).

\footnotetext{
${ }^{1}$ Abstract of "Geologia perimetrului comunei Țaga"- by I. Mârza (from "Monografia comunei Țaga"; in press)

${ }^{2}$ Babeş-Bolyai University, Department of Mineralogy, Str. M. Kogălniceanu -1, Cluj-Napoca

${ }^{3}$ Sabău E. (1984). Analiza datelor şi informațiilor obținute prin lucrări de prospecțiune, explorare şi exploatare efectuate pe structura Țaga, jud Cluj. Lucrare de diplomă. Univ. Babeş-Bolyai, Cluj-Napoca, Biblioteca de Geologie.
} 
- Vântu et al (1998) ${ }^{4}$ - presents a geology report on the gas structures (Țaga, Strugureni etc), with some data concerning the drillings and surface geology.

- Other brief on geology data belongs to Vancea $(1929,1938,1960)$, Pătruț (1948-1949), Răileanu (1952), Ciocârdel (1952), Maxim (1960), Mârza and Mészáros (1991), Mârza et al. (1991).

\section{Stratigraphic remarks:}

- Late Badenian - exclusively identified by the geologist team from Gas Metan Mediaş in boreholes based on microfauna (Vântu et al., 1998). It develops above the salt horizon along a $800 \mathrm{~m}$ wide strip. Lithologically it is represented by sands with slim bands of clayey marls; the Badenian formations are the host rocks of the natural gas.

- Sarmatian - all geological formations that appear on the surface, including those 200 to $300 \mathrm{~m}$ deep from the lowest relief which corresponds to the valleys, belong to the Sarmatian. They mainly develop on a lithologic column of approximately 500 to 600 m wide.

Lithologically, the Sarmatian formations are mainly formed out of sands with slim bands of clayey marls; they vary in dimension, from bands that are fractions of inches wide to chocks or benches of about $10 \mathrm{~m}$. From place to place, the sands are slightly cemented, with rare instances of strong cementation (taupy sandstone). Within the sands there are several types of sandstone concretions: spheric - frequent occurrences, disc- like, rare occurrences, cylindrical, plan-convexical, entwined and incorporated in newer concretions, incidental occurrences. The Volcanic Tuff horizons (the Hădăreni Tuff and the Ghiriş Tuff) complete the lithology of the Sarmatian deposits (Fig. 1).

Fauna - a close examination of the stratification plans within the clayey marl pellites, yields few examples of macrofauna represented by casts of Ervilia and Abra. There are some compact rock areas where these forms occur frequently (1-2 examples in an $20 \mathrm{~cm}$ square area, eg. Râpa Dracului from Ghiolț/Ṭaga, a fossiliferous occurrence identified in 1957 by Mârza.

The fossiliferous level located below the Ghiriş Tuff (Mârza, 1960) represents a particular case. It is characterized by frequent occurrences of lamellibranchiate specimens, but the genus types are scarce (fig. 1). Especially common occurrences are the Ervilia and the small size gasteropodes (Mohrensternia). The microfauna is abundant at this fossiliferous level where other fragments of fish can also be found, such as otolithes, and very rarely small sized teeth.

The volcanic tuffs in this area are levels of volcanic tuffs of extrabasinal origin. From the bottom part of the geological formations in the outcrop, towards the top, the following intrasarmatian levels are present within outcrops:

\footnotetext{
${ }^{4}$ Vântu C., Alexandru F., Frâncu P., Negoescu G., Cişmaru A., Olteanu M., Gheorghi L., Gliga Mihaela, Farkas Monica, Barbu I. (1989). Evaluarea resurselor geologice şi a perimetrelor în exploatare a zăcământului comercial Țaga, la data de 1.01.1989. M. I. Romgaz R. A. Gaz Metan Mediaş (Raport geologoic). 28
} 
A STUDY ON THE GEOLOGY OF THE ȚAGA REGION (CLUJ DISTRICT)

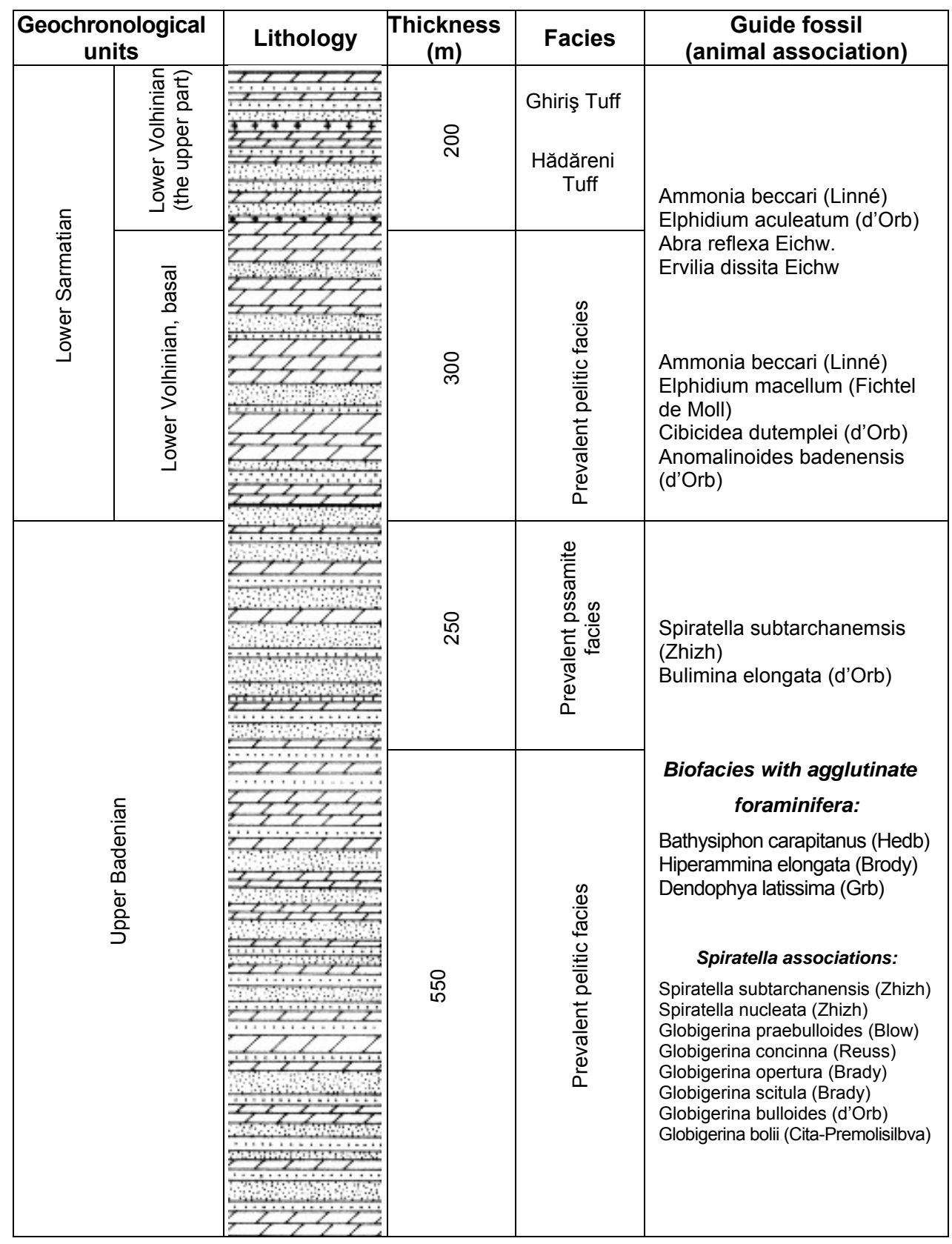

123 近 3

Fig.1. Synoptic lithostratigraphic column of the geological formations from the Taga structure; accordingly the Mediaş Gas Enterprise, Sabău (1984) ${ }^{3}$, with annotations and supplementary data. Legend: 1-Cemented sands and sandstones; 2- Clayey marl pellites; 3-Volcanic tuffs 
- The Hădăreni Tuff (dacite)- mentioned in this area for the first time, it appears in the Sântejude area, Sântejude Vale, and Husuierului Valley; it measures 4 $4.5 \mathrm{~m}$ in width (fig.3).

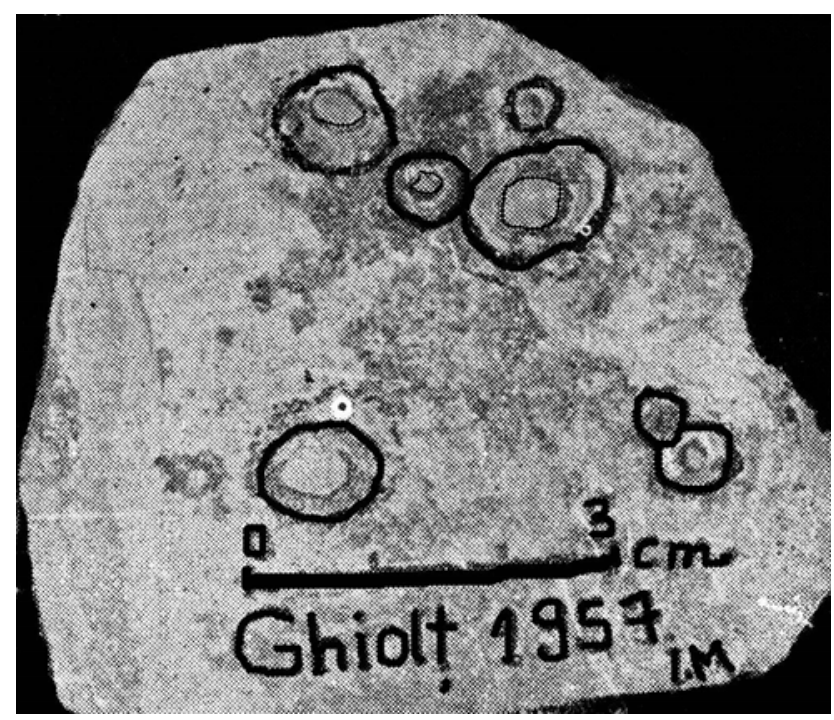

Fig. 2 The frequency of macrofossils (Ervilia) in the fossilliferous level under the GhirişTuff

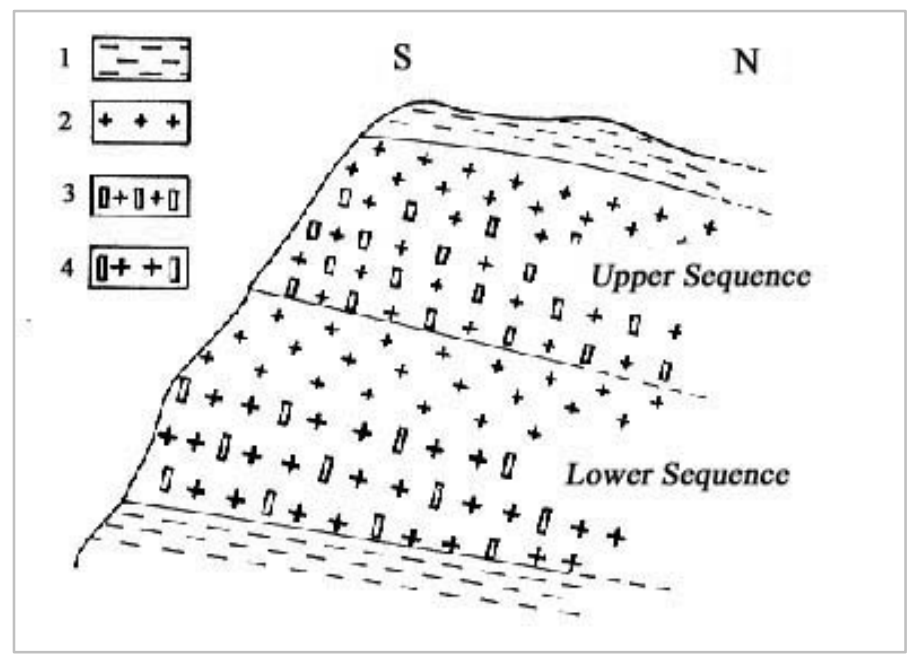

Fig. 3 Lithological column through the Hădăreni Tuff (the left slope of the Codomarc Valley). Legend: 1 - marls; 2 - vitroclastic tuff; 3 - crystalloclastic tuff; 4 - vitrocrystalloclastic tuff; Upper Sequence (1.80 m); Lower Sequence $(2.30 \mathrm{~m})$ 
- The Codomarc Tuff (named and identified by Marza, 2000) runs about $50 \mathrm{~m}$ above the Hădăreni Tuff and measures $10 \mathrm{~cm}$ width (the clayey marl pellites within which this tuff is situated, often contain well preserved specimens of Ervilia).

- The Ghiriş Tuff (andesitic) - outcrops without interruption on the right slope of the Fizeş Valley; it is mapped from the Lacu village (S), to the right slope of the Sărmătin Valley, along aprox. $15 \mathrm{~km}$; the 1.35 to $1.40 \mathrm{~cm}$ tuff horizon maintains this consistent width. On the left slope of the Fizeş Valley, the Ghiriş Tuff occurs in the Sucutard and Țaga areas, to the South, while to the North, due to tectonic consequences, its occurrence in outcrops is problematic.

- The Vulturul Fizeş Tuff - identified by Mârza în 1957 - is situated in the Vulturul Fizeş Hill (outside of the Țaga perimeter), and measures around $50 \mathrm{~cm}$ in width; it is the last level of Sarmatian tuff in the region.

The Taga gas structure lies to the NW of the Transylvania Depression; it has been underlined through field studies and drillings $(1965-1975)$ by the team of geologists from the Mediaş Gas Enterprise. It is part of a larger gas field, developed on a dome structure (Fig.4).

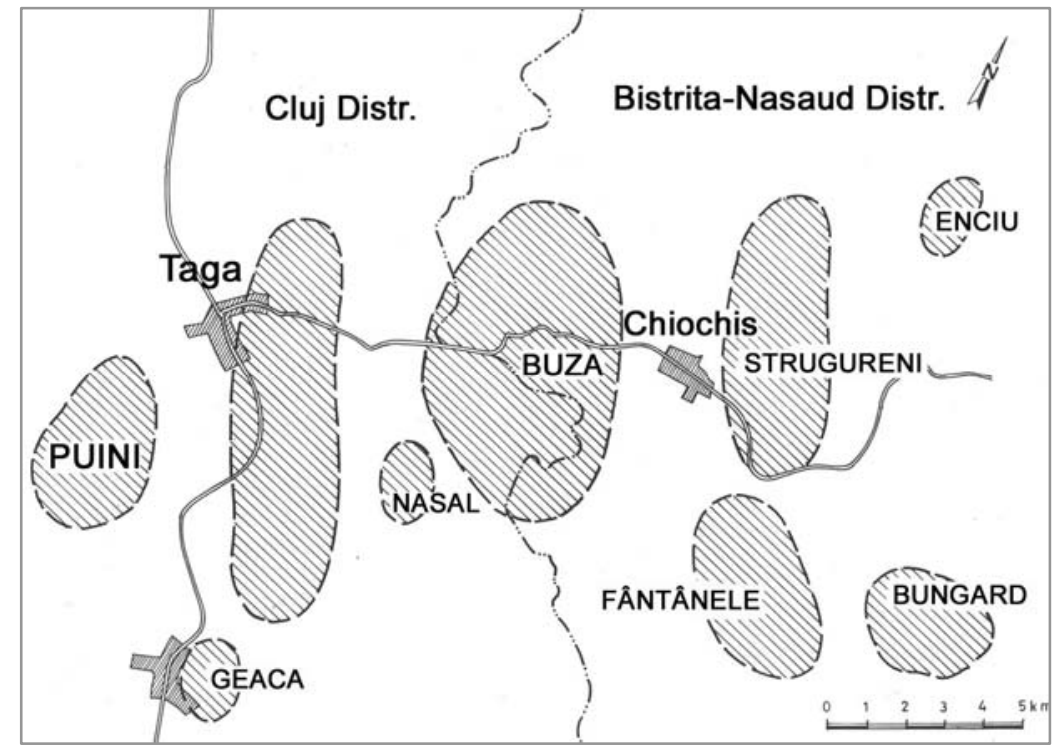

Fig. 4. The Thaga gas structure from the dome gas fields in NW Transylvania; after the "EXPROGAS S.A. Tg. Mureş" data.

The gas accumulations are amassed in Badenian, they are grouped in thirteen complexes and they belong to the structural, lithological and mixed traps (Fig. $5 ; 3$ column). Noteworthy in the chemical composition of the gases is the high methane purity, $97,85-99,33 \%$. 
IOAN MÂRZA

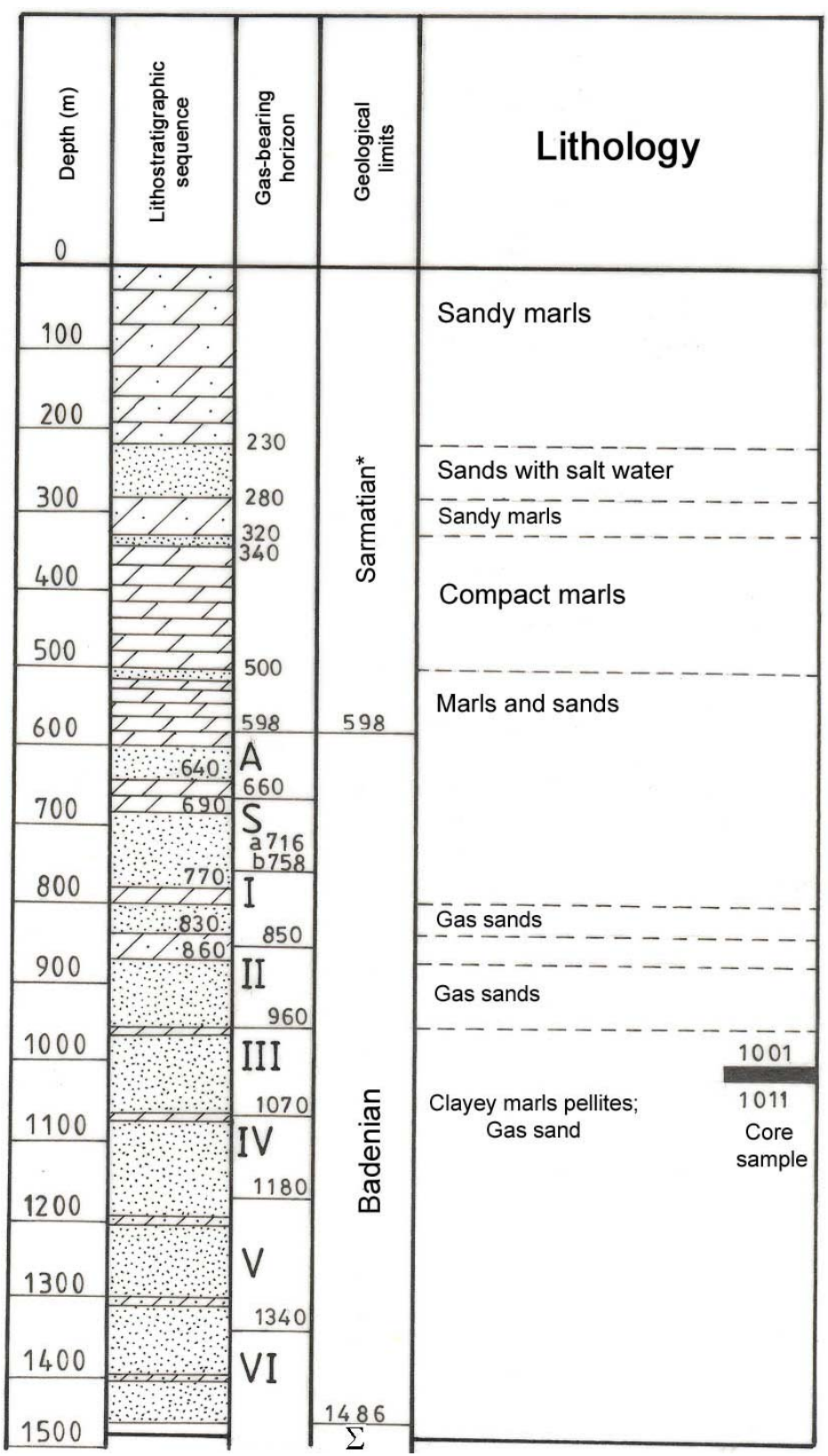

*Buglovian according to "EXPROGAZ" S.A. - Tg-Mureş data

Fig. 5. The localization of the gas horizons in the Taga structure (Badenian); after the "EXPROGAZ S.A. Tg. Mureş" data. 
Tectonics - from a tectonic point of view the Țaga region is marked by the following types of structures:

- Disjunctive tectonics - expressed through faults in the northwestern part of the region (Sântejude, Sântejude Vale, Sântioana)

- Diapirism Effects - in the northwestern part, they are recognized through the presence of salt-water springs (Sântioana); also in the gas dome structures.

\section{Economic resources:}

The area is poor in subsurface resources. Among the few we will mention:

- Raw materials: sands, sometimes sandstone, and volcanic tuffs may also be rarely used (eg. Hădăreni Tuff from the Sântejude Vale area); the clayey marl deposits are used locally for bricks production.

- Natural Gas - methane gas, introduced in the national economic circuit in 1982, and at a later date, locally in Țaga, is the most important exploited geological resource in the region.

- A salt-water spring (Sântioana)- known and minimally fitted out by the locals, used to treat rheumatism.

Conclusion: a hilly relief with valleys marked by extensive marsh lands characterizes the Țaga region. The geological formations, poor in fossils - sands with pellitic, clayey marl bands - have been identified in boreholes, and outcrops. The formations belong to the Badenian and Sarmatian. The Badenian hosts natural gas, which are exploited and used nation wide.

\section{REFERENCES}

Ciocârdel, R.,1952, Contribuții la cunoaşterea geologiei reg. Bistrița - Reghin. D. de S. ale Şed. Inst. Geol., XXXVI, 146 - 151, Bucureşti.

Koch, A., 1900,. Az Erdélyrészi medencze harmadkori képzödményei Neogén csoport, Földt. Int. Ėv. Jelent., 329 p., Budapest.

Maxim, I. Al., 1940,. Un crâmpei din evoluția hidrografică a câmpiei ardelene: valea Coastei. Bul. Soc. reg. rom. Geogr.., LIX, 425 - 439, Bucureşti.

Mârza, I., 1960, Date noi asupra vârstei tufului de Ghiriş. Studia Univ. Babeş-Bolyai, Ser. II, 1, Geol.-Geogr., 121 - 134, Cluj.

Mârza, I., 1962, Contribuții la petrografia tufului de Ghiriş. Stud. şi cercet. de geol., 1, VII, 83 101, Bucureşti.

Mârza, I., Mészáros, N., 1991, Les tufs volcaniques de Transylvanie: historique, valeur théorique et pratique dans le développement de la géologie Transylvaine. In: The volc. tufs from the Transylvanian Basin, Romania. Univ. of. Cluj-Npoca, 11 - 21, Cluj-Napoca (Edit. I.Mârza).

Mârza, I., Niță, P., Niță, S., 1991, Considérations sur la répartition et les sources volcaniques des principaux horizons de tufs de la Dépression de Transylvanie, sur la base des données de forage. The volc. tufs from the Transylvanian Basin, Romania. Univ. of Cluj-Napoca, 191 - 199 Cluj-Napoca (Edit. I. Mârza). 
IOAN MÂRZA

Pătrut,, I., 1948 - 1949, Geologia regiunii Beclean (jud. Someş). D. de S. ale Şed. Com. Geol., XXXVI, 96 - 106, Bucureşti.

Răileanu, Gr., 1952, Cercetări geologice în reg. Cluj - Apahida - Sic. D. de S. ale Şed., XXXIX, 128 - 140, Bucureşti.

Săndulache, Al. ,1970, Lacurile din Câmpia Transilvaniei.

Vancea, A., 1929, Observațiuni geologice în regiunea de S - V a Câmpiei Ardelene. Teză, Mediaş (nepublicat).

Vancea, A., 1938, Contributions à l'étude géologique de la formation à gaz de la Cuvette Transylvaine. An. Inst. Geol., XIX, 293 -321, Bucureşti.

Vancea, A., 1960, Neogenul din Bazinul Transilvaniei. Edit. Acad. R.P. România, 263 p., Bucureşti.

Wein, G., 1941-1942, Búza - Noszoly (Szolnok-Doboka vm.) környékének földtani viszonyai. Földt. Int. Évi Jelent., vol. II, 99 - 106, Budapest. 